\title{
PENGARUH KEPUASAN KERJA, MOTIVASI, KOMUNIKASI INTERPERSONAL, SELF ESTEEM DAN SELF EFFICACY TERHADAP KINERJA INDIVIDUAL (Studi Empiris pada Distributor Tiens Unicore di Makassar)
}

\author{
Zainuddin \\ Fakultas Ekonomi Universitas Khairun Ternate \\ Jl. Pertamina Kelurahan Gambesi Kota Ternate Selatan \\ Email: jhay21.zainuddin@gmail.com
}

Abstract

This study aims to know Influence of Job Satisfaction, Motivation, Interpersonal Communication, Self Esteem and Self Efficacy to Individual Performance. This research was conducted by taking sample 96 active Distributor people of company Tiens Unicore in Makassar. Data Collecting by using Questioner sent direct by researcher and also researcher friend with admission filling deadline three days. Analysis method which used in this research is doubled regression analysis. Result of this research indicated that 1) Job Satisfaction have an effect on significant to Individual Performance. 2) Motivation have an effect on significant to Individual Performance. 3) Interpersonal communication not have an effect on significant to Individual Performance. 4) Self Esteem have an effect on significant to Individual Performance. 5) Self Efficacy have an effect on significant to Individual Performance.

Keywords: job satisfaction, motivation, interpersonal communication, self esteem, self efficacy and individual performance

Abstrak

Tujuan penelitian ini untuk mengetahui pengaruh kepuasan kerja, motivasi, komunikasi interpersonal, self esteem dan self efficacy terhadap kinerja individu. Penelitian ini dilakukan dengan mengambil sampel 96 orang distributor aktif 
perusahaan Tiens Unicore di Makassar. Pengumpulan data dengan menggunakan kuesioner yang diberikan langsung oleh peneliti selama 3 hari. Metode analisis dalam penelitian ini adalah regresi berganda. Hasil penelitian ini menunjukkan bahwa; 1) Kepuasan kerja berpengaruh signifikan terhadap kinerja individu. 2) Motivasi berpengaruh signifikan terhadap kinerja individu. 3) Komunikasi Interpersonal tidak berpengaruh signifikan terhadap kinerja individu. 4) Self esteem berpengaruh signifikan terhadap kinerja individu. 5) Self efficacy berpengaruh signifikan terhadap kinerja individu.

Kata kunci: kepuasan kerja, motivasi, komunikasi interpersonal, self esteem, self efficacy dan kinerja individual

\section{PENDAHULUAN}

Banyak penelitian-penelitian akuntansi yang mencoba mencari pemahaman hubungan antara kepuasan kerja dan kinerja individual. Beberapa penelitian menyatakan bahwa ada hubungan positif antara kepuasan kerja dan kinerja individual (Parker dan Kleemeir, (1951), Vroom (1960), dan Strauss (1968) dalam Supomo (2001). Penelitian yang menguji hubungan antara kepuasan kerja dan kinerja individual masih tidak jelas. Meta analisis yang dilakukan oleh Muchinsky (1986) dalam Engko (2006) menemukan korelasi yang signifikan antara kedua variabel tersebut. Penelitian yang dilakukan oleh Ostroff (1992) memberikan bukti empiris bahwa kepuasan kerja tidak mempunyai hubungan yang signifikan dengan peningkatan kinerja individual.

Ketidakjelasan hubungan antara kepuasan kerja dan kinerja individual mendorong Engko (2006) untuk melakukan pengujian kembali hubungan antara kepuasan kerja dengan kinerja individual dengan menggunakan self esteem dan self efficacy sebagai variabel intervening. Untuk melihat apakah self esteeem dan self efficacy dapat memediasi hubungan antara kepuasan kerja dan kinerja individual, dimana self esteem adalah suatu keyakinan nilai diri sendiri berdasarkan evaluasi diri secara keseluruhan. Perasaan-perasaan self esteem, pada kenyataannya terbentuk oleh keadaan kita dan bagaimana orang lain memperlakukan kita. Seseorang dengan self esteem yang tinggi dimana mereka melihat dirinya berharga, mampu dan dapat diterima. Orang dengan self esteem rendah tidak merasa baik dengan dirinya (Kreitner \&Kinicki, 2003), sedangkan self efficacy adalah keyakinan seseorang mengenai peluangnya untuk berhasil mencapai tugas tertentu (Kreitner\&Kinicki, 2003). Hasil penelitian Engko (2006) menunjukkan bahwa kepuasan kerja berpengaruh signifikan terhadap kinerja individual namun kepuasan kerja tidak berpengaruh signifikan terhadap self esteem dan self efficacy.

Penelitian ini merujuk pada penelitian Engko (2006) dengan menambahkan variabel motivasi dan komunikasi interpersonal serta self esteem dan self efficacy 
untuk menguji pengaruhnya terhadap kinerja individual. Motivasi adalah keadaan internal yang menyebabkan seseorang bertindak, mendorong seseorang pada arah tertentu, dan menjaga sesorang tetap bekerja pada aktivitas tertentu (Elliott, dkk., 2000) dalam Engko (2006) dan Komunikasi memelihara motivasi dengan memberikan penjelasan kepada para seseorang tentang apa yang harus dilakukan, seberapa baik mereka mengerjakannya dan apa yang dapat dilakukan untuk meningkatkan kinerja jika sedang berada di bawah standar (Bandura, 1997).

Salah satu sistem pemasaran baru yang saat ini sedang populer di Indonesia adalah sistem pemasaran yang mendasarkan pada konsep network marketing yaitu konsep pemasaran yang berorientasi seratus persen pada konsumen, konsep tersebut berbeda dengan konsep pemasaran konvensional yang lebih berorientasi pada produk. Pemasaran jaringan merupakan sebagian dari sebutan orang mengenai sistem bisnis yang pemasaran produk/jasanya dilakukan oleh individu (perseorangan) untuk kemudian membentuk jaringan kerja guna memasarkan barang atau jasa. Hasil penjualan pribadi dan jaringan tersebut tiap bulan, perusahaan akan memperhitungkan bonus atau komisi sebagai hasil usaha. Besar kecilnya bonus atau komisi ditentukan oleh tinggi rendahnya peringkat serta omset di bulan tersebut.

Kiyosaki (2001:4) mengungkapkan bahwa mengapa beberapa orang bekerja lebih sedikit, tapi menghasilkan lebih banyak dan lebih aman secara finansial daripada orang lain. Ini hanya masalah mengetahui dari kuadran mana seseorang harus bekerja dan kapan. Ada empat kuadran orang memperoleh penghasilan yaitu employee (pegawai), self-employeed (pekerja lepas), business owner (pemilik usaha), atau sebagai investor (penanam modal). Network Marketing menurut kiyosaki berada di kuadran kanan yaitu business owner.

Salah satu perusahaan yang menggunakan sistem pemasaran jaringan adalah Tiens International dengan support system Unicore. Fakta yang ada sekarang bahwa distributor Tiens Unicore mempunyai kinerja yang bervariasi. Hal ini dapat dilihat dari pencapaian current achievment setiap bulan dimana terdapat perbedaan pencapaian kinerja antara satu distributor dengan distributor lainnya. Kesuksesan seseorang dalam menjalankan sistem usaha mandiri (network marketing) ditentukan oleh kinerja dari orang itu sendiri. Dibutuhkan seseorang yang mempunyai motivasi, komunikasi yang baik dan kemampuan kerja yang tinggi untuk mencapai kinerja yang baik sehingga tercipta kepuasan kerja.

Network marketing lebih mengutamakan pengembangan sumber daya manusia sebagai sumber daya yang tidak terbatas. Ungkapan tersebut dapat dipahami karena usaha ini menekankan suatu bentuk usaha mandiri sehingga keaktifan distributor untuk mencapai omset bulanan adalah kuncinya. Perusahaan akan memberikan kompensasi berupa bonus prestasi kepada distributor berdasarkan persentasi tertentu yang terdapat dalam system marketing plan sebagai upaya untuk membantu mereka guna mengembangkan terus potensi diri serta mampu bekerja berdasar perencanaan yang matang sehingga mampu mendorong kinerja individualnya. 
Atas dasar inilah maka penulis tertarik untuk melakukan penelitian dengan objek yaitu distributor Network Marketing Tiens International dengan support system Unicore karena melihat fenomena yang terjadi banyak distributor merasa dirinya tidak berarti di lingkungannya sehingga membuatnya merasa terasingi, minder, malu, tidak percaya diri, tertekan dan memiliki keyakinan bahwa dia tidak mampu untuk menjalani tugasnya sebagai seorang distributor yang harus presentasi, memperkenalkan bisnisnya kepada orang lain, memotivasi diri dan jaringannya untuk mencapai sukses. Banyak yang menjadikan profesinya sebagai suatu beban sehingga dapat menurunkan kepuasan, motivasi dan kinerjanya. Untuk itu dengan memiliki self esteem yang tinggi, di mana seseorang merasa dirinya berharga, berarti dan jika mereka memilki self efficacy yang tinggi dibarengi dengan kemampuan komunikasi yang baik, para distributor merasa yakin dengan kemampuannya untuk berhasil maka sangat mendukung karier maupun kinerjanya sebagai seorang distributor.

\section{TINJAUAN PUSTAKA}

\section{Kepuasan Kerja}

Untuk mengetahui tentang pengertian kepuasan kerja ada beberapa pendapat sebagaimana hasil penelitian Herzberg, bahwa faktor yang mendatangkan kepuasan adalah prestasi, pengakuan, pekerjaan itu sendiri, tanggung jawab, dan kemajuan. Pendapat lain menyatakan kepuasan kerja (job satisfaction) adalah keadaan emosional yang menyenangkan atau tidak menyenangkan di mana seseorang memandang pekerjaan mereka (Handoko, 2001). Sedangkan Wexley dan Yulk (1977) dalam Prasetyo, dkk. (2005) yang disebut kepuasan kerja ialah perasaan seseorang terhadap pekerjaan. Seseorang cenderung bekerja dengan penuh semangat apabila kepuasan dapat diperolehnya dari pekerjaannya dan kepuasan kerja pekerja merupakan kunci pendorong moral, kedisiplinan dan prestasi kerja pekerja dalam mendukung terwujudnya tujuan perusahaan (Hasibuan, 2003:93).

Sejalan dengan itu, Martoyo (2000:142) mengemukakan bahwa kepuasan kerja (job satisfaction) adalah keadaan emosional seseorang dalam hal ini distributor dimana terjadi maupun tidak terjadi titik temu antara nilai balas jasa kerja seseorang dari perusahaan atau organisasi dengan tingkat nilai balas jasa yang memang diinginkan oleh orang yang bersangkutan. Balas jasa seseorang ini, baik yang berupa finansial maupun non finansial. Kepuasan kerja merupakan persoalan umum pada setiap unit kerja, baik itu berhubungan motivasi, kesetiaan ataupun ketenangan bekerja dan disiplin kerja.

Engko (2006) menyatakan faktor-faktor yang memberikan kepuasan kerja adalah: (a) faktor individual, meliputi umur, kesehatan, watak dan harapan; (b) faktor sosial, meliputi hubungan kekeluargaan, pandangan masyarakat, kesempatan berekreasi, kegiatan perserikatan pekerja, kebebasan berpolitik, dan hubungan kemasyarakatan; (c) faktor utama dalam pekerjaan, meliputi upah, pengawasan, 
ketentraman kerja, kondisi kerja, dan kesempatan untuk maju. Selain itu, juga penghargaan terhadap kecakapan, hubungan sosial di dalam pekerjaan, ketepatan dalam menyelesaikan konflik antar manusia, perasaan diperlakukan adil baik yang menyangkut pribadi maupun tugas.

Kepuasan kerja dalam teori motivasi Maslow menempati peringkat yang tinggi. Sebab ia berkaitan dengan tujuan manusia untuk merealisasikan dan mengaktualisasikan potensi dirinya dalam pekerjaan. Namun motivasi ini kadang terbendung oleh berbagai ragam kerutinan, hambatan lingkungan kerja yang kurang seimbang, atau situasi dan perangkat kerja yang secara ergonomis tidak mendukung peningkatan produktivitas kerja. Stres yang dialami seseorang utamanya distributor dan kepuasan kerja yang didambakan seolah merupakan dua kondisi yang bukan saja berkaitan, tetapi sekaligus antagonistis.

\section{Motivasi}

Menurut Siagian (2002:255), menyatakan bahwa yang diinginkan seseorang dari pekerjaannya pada umumnya adalah sesuatu yang mempunyai arti penting bagi dirinya sendiri dan bagi perusahaan, yang mana menurut Heidjachman, dkk. (2003:197) motivasi merupakan proses untuk mencoba mempengaruhi seseorang agar melakukan sesuatu yang kita inginkan. Untuk membangun produktivitas dan motivasi pekerja ada dua hal yang harus dilakukan: pertama, carilah pembayaran pekerjaan individual seseorang; dan kedua, bantu mereka mencapai pembayaran untuk setiap tugas tambahan yang diberikan sehingga baik kebutuhan pemerintah maupun individu tercapai (Timpe, 1999: 61). Untuk memahami tentang motivasi lebih jauh, kita akan membahas beberapa teori tentang motivasi, antara lain:

1) Teori Abraham H. Maslow (Teori Kebutuhan) - 1943-1970; Teori motivasi yang dikembangkan oleh Abraham H. Maslow pada intinya berkisar pada pendapat bahwa manusia mempunyai lima tingkat atau hierarki kebutuhan, yaitu: (1) kebutuhan fisiologikal (physiological needs), seperti: rasa lapar, haus, istirahat dan sex; (2) kebutuhan rasa aman (safety needs), tidak dalam arti fisik semata, akan tetapi juga mental, psikologikal dan intelektual; (3) kebutuhan akan kasih sayang (love needs); (4) kebutuhan akan harga diri (esteem needs), yang pada umumnya tercermin dalam berbagai simbol-simbol status; dan (5) aktualisasi diri (self actualization), dalam arti tersedianya kesempatan bagi seseorang untuk mengembangkan potensi yang terdapat dalam dirinya sehingga berubah menjadi kemampuan nyata.

2) Teori McClelland (Teori Kebutuhan Berprestasi) - 1961; Dari McClelland dikenal tentang teori kebutuhan untuk mencapai prestasi atau Need for Acievement (N.Ach) yang menyatakan bahwa motivasi berbeda-beda, sesuai dengan kekuatan kebutuhan seseorang akan prestasi. Murray merumuskan kebutuhan akan prestasi tersebut sebagai keinginan (1) melaksanakan sesuatu tugas atau pekerjaan yang sulit. (2) menguasai, memanipulasi, atau mengorganisasi obyek-obyek fisik, manusia, 
atau ide-ide. (3) melaksanakan hal-hal tersebut secepat mungkin dan seindependen mungkin, sesuai kondisi yang berlaku. (4) mengatasi kendala-kendala, mencapai standar tinggi. (5) mencapai performa puncak untuk diri sendiri. (6) mampu menang dalam persaingan dengan pihak lain. (7) meningkatkan kemampuan diri melalui penerapan bakat secara berhasil.

3) Teori Clyton Alderfer (Teori ERG); Teori Alderfer dikenal dengan akronim "ERG". Akronim "ERG" dalam teori Alderfer merupakan huruf-huruf pertama dari tiga istilah yaitu: $\mathrm{E}=$ Existence (kebutuhan akan eksistensi), $\mathrm{R}=$ Relatedness (kebutuhan untuk berhubungan dengan pihak lain, dan $\mathrm{G}=$ Growth (kebutuhan akan pertumbuhan). Jika makna tiga istilah tersebut di dalami akan tampak dua hal penting. Pertama, secara konseptual terdapat persamaan antara teori atau model yang dikembangkan oleh Maslow dan Alderfer. Karena "Existence" dapat dikatakan identik dengan hierarki pertama dan kedua dalam teori Maslow; "Relatedness" senada dengan hierarki kebutuhan ketiga dan keempat menurut konsep Maslow dan "Growth" mengandung makna sama dengan "self actualization" menurut Maslow. Kedua, teori Alderfer menekankan bahwa berbagai jenis kebutuhan manusia itu diusahakan pemuasannya secara serentak.

4) Teori Herzberg (Teori Dua Faktor) - 1966; Ilmuwan ketiga yang diakui telah memberikan kontribusi penting dalam pemahaman motivasi Herzberg. Teori yang dikembangkannya dikenal dengan "Model Dua Faktor" dari motivasi, yaitu faktor motivasional dan faktor hygiene atau "pemeliharaan". Menurut teori ini yang dimaksud faktor motivasional adalah hal-hal yang mendorong berprestasi yang sifatnya intrinsik, yang berarti bersumber dalam diri seseorang, sedangkan yang dimaksud dengan faktor hygiene atau pemeliharaan adalah faktor-faktor yang sifatnya ekstrinsik yang berarti bersumber dari luar diri yang turut menentukan perilaku seseorang dalam kehidupan seseorang.

\section{Komunikasi Interpersonal}

Pada dasarnya pengertian komunikasi memiliki karakteristik yang tidak jauh berbeda dengan ilmu sosial lainnya. Hanya saja dalam ilmu komunikasi objeknya ditujukan kepada peristiwa-peristiwa komunikasi antar manusia (Mulyana, 2000:60). Hubungan manusiawi yang termasuk ke dalam komunikasi interpersonal (interpersonal communication) disebut juga human relation sebab berlangsung pada umumnya antara dua orang secara dialogis. Dikatakan bahwa hubungan manusiawi itu komunikasi karena sifatnya yang action oriented, mengandung kegiatan untuk mengubah sikap, pendapat atau perilaku seseorang (Onong, 2001:56).

Human relation adalah komunikasi antar pribadi yang manusiawi berarti komunikasi yang telah memasuki tahap psikologis yang komunikator dan komunikannya saling memahami pikiran, perasaan dan melakukan tindakan bersama. Ini juga berarti bahwa apabila kita hendak menciptakan suatu komunikasi yang penuh 
dengan keakraban yang didahului oleh pertukaran informasi tentang identitas dan masalah pribadi yang bersifat sosial (Liliweri, 1997:213)

Menurut Effendy (2003) teori dan model komunikasi yang tampil pada tahun awal sekitar dekade 1940-an dan 1950-an adalah sebagi berikut:

Lasswell's Model (Model Lasswell); Teori komunikasi yang dianggap paling awal (1948). Lasswell menyatakan bahwa cara yang terbaik untuk menerangkan proses komunikasi adalah menjawab pertanyaan: Who says in which channel to whom with what effect (Siapa mengatakan apa melalui saluran apa kepada siapa dengan efek apa). Jawaban bagi pertanyaan paradigmatik: Lasswell itu merupakan unsur-unsur proses komunikasi yaitu Communicator (komunikator), Message (pesan), Media (media), Receiver (komunikan/penerima), dan Effeck (efek).

S-O-R Theory (Teori S-O-R); Teori S-O-R singkatan dari Stimulus-OrganismResponse ini semua berasal dari psikologi. Objek material dari psikologi dan ilmu komunikasi adalah sama yaitu manusia yang jiwanya meliputi komponen-komponen: sikap, opini, perilaku, kognisi afeksi dan konasi.

S-M-C-R model (Model S-M-C-R: Rumus S-M-C-R adalah singkatan dari istilah-istilah: S singkatan dari Source yang berarti sumber atau komunikator; $\mathrm{M}$ singkatan dari Message yang berarti pesan; $\mathrm{C}$ singkatan dari Channel yang berarti saluran atau media, sedangkan $\mathrm{R}$ singkatan dari Receiver yang berarti penerima atau komunikan.

The Mathematical Theory of Communication (Teori Matematika Komuikasi); Teori matematikal ini acapkali disebut model Shannon dan Weaver, oleh karena teori komunikasi manusia yang muncul pada tahun 1949, merupakan perpaduan dari gagasan Claude E. Shannon dan Warren Eaver. Shannon pada tahun 1948 mengetengahkan teori matematik dalam komunikasi permesinan (engineering communication), yang kemudian bersama Warren pada tahun 1949 diterapkan pada proses komunikasi manusia (human communication).

\section{Self Esteem}

Self esteem adalah suatu keyakinan nilai diri sendiri berdasarkan evaluasi diri secara keseluruhan. Perasaan-perasaan self esteem, pada kenyataannya terbentuk oleh keadaan kita dan bagaimana orang lain memperlakukan kita. Self esteem diukur dengan pernyataan positif maupun negatif. Pernyataan positif pada survei self esteem adalah "saya merasa bahwa saya adalah seseorang yang sangat berarti, seperti orang lainnya". Sedangkan pernyataan-pernyataan yang negatif adalah "saya merasa bahwa saya tidak memiliki banyak hal untuk dibanggakan". Orang yang sepakat dengan pernyataan positif dan tidak sepakat dengan pernyataan negatif memiliki self esteem yang tinggi dimana mereka melihat dirinya berharga, mampu dan dapat diterima. Orang yang dengan self esteem rendah tidak merasa baik dengan dirinya (Kreitner \& Kinicki, 2003). 


\section{Self Efficacy}

Bandura (1997) mendefinisikan self efficacy sebagai judgment individu atas kemampuan mereka untuk mengorganisasi dan melakukan serangkaian tindakan yang diperlukan untuk mencapai tingkat kinerja yang ditentukan. Self efficacy menurut Bandura dapat ditumbuhkan dan dipelajari melalui berbagai sumber yaitu: (1) kinerja atau pengalaman masa lalu; (2) model perilaku (mengamati orang lain yang melakukan tindakan yang sama); (3) persuasi dari orang lain dan keadaan faktor fisik dan emosional. Pencapaian prestasi merupakan sumber pengharapan efficacy yang terbesar karena didasarkan pada pengalaman-pengalaman pribadi individu berupa keberhasilan atau kegagalan.

Self efficacy adalah keyakinan seseorang mengenai peluangnya untuk berhasil mencapai tugas tertentu (Kreitner \& Kinicki, 2003). Menurut Philip dan Gully (1997) dalam Engko (2006) self efficacy dapat dikatakan sebagai faktor personal yang membedakan setiap individu dan perubahan self efficacy dapat menyebabkan terjadinya perubahan perilaku terutama dalam penyelesaian tugas dan tujuan. Penelitiannya menemukan bahwa self efficacy berhubungan positif dengan penetapan tingkat tujuan. Individu yang memiliki self efficacy tinggi akan mampu menyelesaikan pekerjaan atau mencapai tujuan tertentu, mereka juga akan berusaha menetapkan tujuan lain yang tinggi.

Teori tentang kinerja adalah teori psikologi tentang proses tingkah laku kerja seseorang sehingga ia menghasilkan sesuatu yang menjadi tujuan dari pekerjaannya. As'ad (2003) mengatakan bahwa perbedaan kinerja antara orang yang satu dengan lainnya di dalam suatu situasi kerja adalah karena perbedaan karakteristik dari individu, di samping itu, orang yang sama dapat menghasilkan kinerja yang berbeda di dalam situasi yang berbeda pula.

Pekerjaan seorang distributor memiliki perbedaan dengan pekerja yang bekerja di bisnis konvensional (employee) sebab pekerja umumnya memiliki ruang lingkup tanggung jawab yang sangat terbatas sesuai dengan job description yang diberikan oleh atasannya, sementara distributor pada dasarnya bertanggung jawab langsung terhadap hampir semua hal yang berkaitan dengan bisnisnya. Perusahaan hanya bertindak sebagai pembimbing dan penyedia barang, sedangkan yang menjalankan tugas pemasaran adalah para anggota atau distributor. Hal-hal yang diduga akan menghambat kinerja distributor antara lain kurang menguasai ilmu, kurang yakin akan kemampuan pribadi, kurang siap menghadapi resiko, keputusasaan, kemalasan. Distributor yang kurang mempunyai motivasi dan kemampuan kerja, maka kinerjanya rendah pula. Hal ini sesuai dengan pendapat Stoner dan Freeman dalam Prasetyo (2005) bahwa ada tiga hal yang mempengaruhi kinerja seseorang yaitu motivasi, kemampuan, dan persepsi peran.

Beberapa definisi mengenai kinerja maka dapat disimpulkan bahwa kinerja adalah hasil yang telah dicapai seseorang dalam pekerjaannya selama periode 
tertentu menurut ukuran yang telah ditentukan terlebih dahulu yang berlaku untuk pekerjaan tersebut.

\section{Kepuasan Kerja dan Kinerja Individual}

Kepuasan kerja dalam teori motivasi Maslow menempati peringkat yang tinggi. Sebab ia berkaitan dengan tujuan manusia untuk merealisasikan dan mengaktualisasikan potensi dirinya dalam pekerjaan. Kepuasan kerja merupakan sikap emosional yang menyenangkan dan mencintai pekerjaannya. Sikap ini dicerminkan oleh moral kerja, kedisiplinan dan prestasi kerja. Kepuasan kerja dapat dinikmati dalam pekerjaan, luar pekerjaan dan kombinasi dalam dan luar pekerjaan. Kepuasan dalam pekerjaan adalah kepuasan kerja yang dinikmati dalam pekerjaan misalnya dengan mendapat pujian hasil kerja, penempatan, perlakuan, peralatan dan suasana lingkungan kerja yang baik. Penelitian yang dilakukan oleh Supomo, dkk. (2001) menyatakan bahwa ada hubungan yang signifikan antara kepuasan kerja dan kinerja individual. Penelitian Engko (2006) menemukan bahwa kepuasan kerja berpengaruh signifakan terhadap kinerja individual. Atas dasar hasil penelitian di atas, maka hipotesis yang dapat disusun adalah sebagai berikut:

H1 : Kepuasan Kerja berpengaruh signifikan terhadap Kinerja Individual

\section{Motivasi dan Kinerja Individual}

Proses motivasi berawal dari adanya kebutuhan yang tidak terpenuhi sehingga menciptakan ketegangan yang menimbulkan dorongan-dorongan dalam diri seseorang. Dorongan-dorongan ini menimbulkan upaya pencarian guna memenuhi atau memuaskan kebutuhan, pada akhirnya tekanan yang dirasakan menurun. Pada saat tekanan menurun, maka motivasi juga menurun. Karena itu, tekanan-tekanan yang proporsional harus dilakukan secara kontinyu agar dorongan untuk bertindak selalu hidup dalam diri seseorang.

Dalam industri pamasaran jaringan, secara individual, upaya motivasi bisa dilakuan melalui upaya-upaya mengontrol, menilai lalu memotivasi diri sendiri. Namun, ada kalanya kesadaran untuk memotivasi diri tidak muncul dalam diri seseorang, karena itu diperlukan motivasi eksternal yang bisa berasal dari upline, keluarga, rekan seproesi, buku bacaan positi, CD/Kaset Network Education Tools Programs dan alat bantu lain. Penelitian yang terkait dengan pengaruh motivasi terhadap kinerja individual, didukung penelitian Efendi (2007) yang menemukan bahwa motivasi kerja mempunyai pengaruh positif terhadap kinerja individual. Atas dasar itu, maka hipotesis yang disusun adalah sebagai berikut:

H2 : Motivasi berpengaruh signifikan terhadap Kinerja Individual 


\section{Komunikasi Interpersonal dan Kinerja Individual}

Komunikasi memelihara motivasi dengan memberikan penjelasan kepada para distributor tentang apa yang harus dilakukan, seberapa baik mereka mengerjakannya dan apa yang dapat dilakukan untuk meningkatkan kinerja jika sedang berada di bawah standar.

Ada dua model komunikasi dalam rangka meningkatkan kinerja dan mencapai tujuan. Pertama, komunikasi koordinatif, yaitu proses komunikasi yang berfungsi untuk menyatukan bagian-bagian (subsistem) organisasi. Kedua, komunikasi interaktif, ialah proses pertukaran informasi yang berjalan secara berkesinambungan, pertukaran pendapat dan sikap yang dipakai sebagai dasar penyesuaian di antara sub-sub sistem dalam organisasi. Frekuensi dan intensitas komunikasi yang dilakukan juga turut mempengaruhi hasil dari suatu proses komunikasi tersebut. Komunikasi interaktif disebut juga dengan komunikasi interpersonal. Penelitian yang terkait dengan pengaruh komunikasi interpersonal terhadap kinerja individual dilakukan Chandra (2007) yang menemukan adanya pengaruh antara komunikasi interpersonal para leader MLM KK terhadap motivasi dan kinerja distributor. Dari asumsi tersebut, dapat dirumuskan hipotesis:

H3 : Komunikasi Interpersonal berpengaruh signifikan terhadap Kinerja Individual

\section{Self esteem dan Kinerja Individual}

Para peneliti mendefnisikan organization based self esteem (OBSE) atau self esteem dalam organisasi sebagai nilai yang dimiliki oleh individu atas dirinya sendiri sebagai anggota organisasi yang bertindak dalam konteks organisasi. Orang yang memiliki skor OBSE tinggi cenderung memandang diri mereka sendiri sebagai orang yang penting, berharga, berpengaruh dan berarti dalam konteks organisasi yang mempekerjakan mereka. (Kreitner \& Kinicki, 2003). Dengan demikian jika seseorang merasa dirinya begitu penting, berharga dan berpengaruh maka timbul kepuasan atas pekerjaan yang dilakukannya karena apa yang dilakukannya berhasil dan menciptakan hasil yang optimal.

Seseorang yang merasa dirinya begitu berharga dan berarti cenderung untuk melakukan yang terbaik dalam setiap tugas dan tanggung jawabnya, baik sebagai anggota organisasi maupun sebagai individual. Dengan demikian maka akan meningkatkan kinerja individualnya. Motivasi yang tinggi yang diikuti dengan self esteem yang tinggi pula akan meningkatkan kienrja seorang distributor. Hasil penelitian Engko (2006) menemukan sebaliknya, kepuasan kerja tidak berpengaruh signifikan terhadap self esteem. Seseorang yang memeiliki kepuasan kerja dan self esteem yang tinggi akan meningkatkan kinerja individualnya. Atas dasar hasil penelitian di atas, maka hipotesis yang dapat disusun adalah sebagai berikut:

H4 : Self esteem berpengaruh signifikan terhadap kinerja individual. 


\section{Self Efficacy dan Kinerja Individual}

Self efficacy merupakan kepercayaan terhadap kemampuan seseorang untuk menjalankan tugas. Orang yang percaya diri dengan kemampuannya cenderung untuk berhasil, sedangkan orang yang selalu merasa gagal cenderung untuk gagal. Self efficacy berhubungan dengan kepuasan kerja dimana jika seseorang memiliki self efficacy yang tinggi maka cenderung untuk berhasil dalam tugasnya sehingga meningkatkan kepuasan atas apa yang dikerjakannya. Hasil penelitian Engko (2006) menemukan tidak adanya pengaruh signifikan antara kepuasan kerja dengan self efficacy

Dalam melakukan tugasnya, distributor perlu memiliki kepribadian yang dapat dikembangkan. Self efficacy merupakan keyakinan individu terhadap kemampuan yang dimilikinya untuk memobilisasi motivasi, sumber daya kognitif dan tindakantindakan yang diperlukan atas situasi-situasi yang dihadapi. Self efficacy yang tinggi akan mengembangkan kepribadian yang kuat, mengurangi stress dan tidak mudah terpengaruh situasi yang mengancam. Sehingga distributor dengan self efficacy yang tinggi diharapkan dapat mencapai kinerja lebih baik karena tidak mudah terganggu oleh situasi yang mengancam. Atas dasar itu, maka hipotesis yang disusun adalah sebagai berikut:

H5 : Self efficacy berpengaruh signifikan terhadap kienrja individual

\section{METODE PENELITIAN}

\section{Populasi dan Sampel}

Data penelitian dikumpulkan dengan kuesioner yang disebarkan kepada sampel Distributor Tiens Unicore di kota Makassar. Alasan memilih kota Makassar karena melihat perkembangan bisnis Tiens Unicoredi kota tersebut yang terbesar jaringannya di luar Jawa. Sampel ini dipilih karena peneliti ingin melihat bagaimanakah pengaruh kepuasan kerja, motivasi, komunikasi interpersonal, self esteem dan self efficacy terhadap kinerja individualnya.

Adapun teknik pengambilan sampel yang digunakan adalah purposive sampling dengan kriteria pemilihan sampel dalam penelitian ini adalah: (a) Sampel penelitian adalah Distributor Tiens Unicore yang masih aktif. Syarat keaktifan dilihat dari hadirnya mereka di pertemuan rutin Unicore di bulan pertama penelitian. (b) Sampel dipilih berdasarkan peringkat Tiens. (c) Data dalam kuesioner diisi lengkap.

\section{Pengukuran Variabel}

\section{Variabel Independen}

$\mathrm{X} 1$ : Kepuasan kerja (job satisfaction) adalah keadaan emosional yang menyenangkan atau tidak menyenangkan di mana seorang distributor memandang pekerjaan mereka. Kepuasan kerja diukur dengan instrumen yang meliputi fakor individual 
meliputi umur, kesehatan dan karakter, faktor sosial yang meliputi hubungan dengan tim bisnis dan masyarakat umum, serta faktor utama dalam pekerjaan meliputi bonus, ketentraman kerja dan kesempatan untuk mencapai impian mereka.

$\mathrm{X} 2$ : Motivasi adalah dorongan yang timbul pada diri seorang distributor baik sadar atau tidak sadar untuk melakukan suatu tindakan dengan tujuan tertentu atau usaha-usaha yang dapat menyebabkannya bergerak melakukan sesuatu karena ingin mencapai tujuan yang dikehendakinya atau mendapat kepuasan atas perbuatannya. Variabel motivasi dalam penelitian ini diukur dengan dua faktor yakni faktor internal meliputi harapan pribadi (dreams), harga diri, kepuasan serta prestasi kerja yang dihasilkan serta faktor eksternal meliputi jenis pekerjaan serta peluang untuk sukses, organisasi tempat bekerja serta imbalan yang berlaku dan cara penerapannya.

X3: Komunikasi memelihara motivasi dengan memberikan penjelasan kepada seseorang tentang apa yang harus dilakukan, seberapa baik mereka mengerjakannya dan apa yang dapat dilakukan untuk meningkatkan kinerja jika sedang berada di bawah standar.

Komunikasi interpersonal diukur dengan pernyataan mengenai komunikasi para leader dengan grup atau jaringannya mengenai pujian, hubungan dengan rekan dan tim kerja, sikap terbuka dan profesionalisme kerja.

X4: Self esteem merupakan evaluasi secara menyeluruh dari dimensi diri. Self esteem juga mengacu pada harga diri atau self image dan merefleksikan kepercayaan diri serta kepuasan individu terhadap diri mereka. Self esteem diukur dengan pernyataan mengenai kepercayaan diri, penghargaan dan potensi untuk sukses.

X5: Self efficacy adalah keyakinan seorang distributor mengenai peluangnya untuk berhasil mencapai impiannya. Self efficacy diukur dengan pernyataan tentang keyakinan seseorang untuk mencapai target yang telah direncanakan dan keyakinan mampu menyelesaikan tugas tertentu.

\section{Variabel Independen}

Y: Kinerja individual mengacu pada prestasi kerja distributor yang diatur berdasarkan standar atau kriteria yang telah ditetapkan oleh perusahaan maupun support system dan tim bisnis yang disebut vital sign. Kinerja individual diukur dengan instrumen mengenai pencapaian distributor dalam organisasi bisnisnya meliputi efisiensi dan keefektifan, otoritas dan tanggung jawab, kedisiplinan, inisiatif dan kepemimpinan.

\section{Pengujian Hipotesis}

Metode analisis yang digunakan untuk menguji hipotesis dalam penelitian ini adalah analisis regresi linear berganda dengan menggunakan program SPSS 14 for windows. Untuk menguji hipotesis yang dikembangkan dalam penelitian ini akandigunakan model sebagai berikut: 
KIN $=\alpha+\beta_{1} K K+\beta_{2} M+\beta_{3}$ Kom $+\beta_{4} S E T+\beta_{5} S E F \in$

Dengan:

$\begin{array}{ll}\text { KIN } & : \text { Kinerja Individual } \\ \alpha & : \text { Konstanta } \\ \beta_{1}-\beta_{5} \beta_{1}-\beta_{5} & : \text { Koefisien regresi } \\ \text { KK } & : \text { Kepuasan Kerja } \\ \mathrm{M} & : \text { Motivasi } \\ \mathrm{SET} & : \text { Self esteem } \\ \mathrm{SEF} & : \text { Self efficacy } \\ \mathrm{e} & : \text { Residual }\end{array}$

Kriteria pengujian yang digunakan adalah:

- Jika $\mathrm{t}_{\text {hitung }}>\mathrm{t}_{\text {tabel }}(\mathrm{n}-\mathrm{k}-1)$ maka H0 ditolak

- Jika $\mathrm{t}_{\text {hitung }}<\mathrm{t}_{\text {tabel }}(\mathrm{n}-\mathrm{k}-1)$ maka H0 diterima

Atau dilihat dari besarnya probabilitas value ( $p$ value) dibandingkan dengan 0,05 ( Taraf signifikansi $\alpha=5 \%$ ). Adapun kriteria pengujian yang digunakan adalah

- Jika $p$ value $<0,05$ maka H0 ditolak

- Jika $p$ value $>0,05$ maka H0 diterima

\section{HASIL PENELITIAN DAN PEMBAHASAN}

\section{Pengambilan Data}

Pengambilan data dilakukan pada bulan Januari 2010 selama 2 minggu. Data yang digunakan pada penelitian ini adalah data primer yang diperoleh dengan memberikan kuesioner kepada responden. Penyebaran kuesioner dilakukan oleh peneliti maupun rekan peneliti secara langsung pada distributor aktif Tiens Unicore di Makassar sebanyak 100 distributor, hal ini dilakukan untuk mendapatkan response rate yang tinggi, dengan tingkat pengembalian instrumen sebanyak 96 (96\%) dan sisanya sebanyak 4 kuesioner atau (4\%) tidak dikembalikan karena responden mengembangkan jaringannya di luar daerah.

\section{Deskripsi Data Penelitian}

Sebagai gambaran umum mengenai penyebaran/distribusi data yang disajikan dan diolah dari data mentah maka digunakan metode statistik deskriptif. Adapun deskripsi data penelitian dapat dilihat dari tabel di bawah ini. 
Tabel 1. Deskripsi Data

\begin{tabular}{lrrrr}
\hline & $\begin{array}{c}\text { N } \\
\text { Statistic }\end{array}$ & $\begin{array}{c}\text { Minimum } \\
\text { Statistic }\end{array}$ & $\begin{array}{c}\text { Maximum } \\
\text { Statistic }\end{array}$ & $\begin{array}{c}\text { Mean } \\
\text { Statistic }\end{array}$ \\
\hline Kepuasan Kerja & 96 & 2.00 & 5.00 & 4.5625 \\
Motivasi & 96 & 3.40 & 5.00 & 4.2948 \\
Komunikasi Interpersonal & 96 & 2.00 & 5.00 & 3.9812 \\
Self esteem & 96 & 2.70 & 5.00 & 4.1354 \\
Self efficacy & 96 & 2.70 & 5.00 & 3.9906 \\
Kinerja Individual & 96 & 3.20 & 5.00 & 4.2271 \\
Valid N (listwise) & 96 & & & \\
\hline
\end{tabular}

Sumber : Olah Data SPSS

Hasil deskripsi tersebut di atas menunjukan bahwa rata-rata responden setuju terhadap kepuasan kerja, motivasi komunikasi interpersonal, self esteem, self efficacy memiliki huhungan dengan kinerja individual.

\section{Uji Hipotesis}

Pengujian hipotestis dengan analisis regresi berganda digunakan untuk menganalisis data dengan tingkat keyakinan $95 \%$ atau tingkat kesalahan yang dapat ditoleransi 5\%. Uji Hipotesis dalam penelitian ini menggunakan metode analisis regresi berganda. Dari hasil pengolahan data yang meliputi variabel-variabel kepuasan kerja (X1), motivasi (X2), komunikasi interpersonal (X3), self esteem (X4), self efficacy (X5) dan kinerja individual (Y) maka diperoleh hasil sebagai berikut:

Tabel.2. Hasil Analisis Regresi Berganda

\begin{tabular}{lccrr}
\hline Variabel & $\begin{array}{c}\text { Koefisien } \\
\text { Regresi }\end{array}$ & $\begin{array}{c}\text { Standardized } \\
\text { Coefisients (Beta) }\end{array}$ & T & Sig \\
\hline (Constant) & 1,719 & 0,219 & 2,693 & 0,008 \\
Kepuasan Kerja & 0,178 & 0,195 & 2,393 & 0,019 \\
Motivasi & 0,182 & 0,190 & 2,054 & 0,043 \\
Komunikasi Interpersonal & 0,165 & 0,232 & 1,797 & 0,076 \\
Self esteem & 0,203 & 0,196 & 2,137 & 0,035 \\
Self efficacy & 0,146 & 2,011 & 0,047 \\
R $\quad$ 0,513,; R Square $=0,263$; Std Error $=0,37832 ; \mathrm{F}$ & $=6,44$ & \\
\hline
\end{tabular}

Sumber: Olah Data SPSS

Berdasarkan hasil tersebut di atas, maka model regresi linier berganda sebagai berikut:

$\mathrm{Y}=1,719+0,178 \mathrm{X} 1+0,182 \mathrm{X} 2+0,165 \mathrm{X} 3+0,203 \mathrm{X} 4+0,146 \mathrm{X} 5+\mathrm{e}$

Berdasarkan pada tabel di atas menunjukkan bahwa $\mathrm{F}_{\text {hitung }}$ adalah 6,440 dengan tingkat signifikansi sebesar 0,000 lebih kecil dari $\alpha=0,05$ sehingga dapat dinyatakan bahwa secara bersama-sama variabel kepuasan kerja, motivasi, komunikasi 
interpersonal, self esteem dan self efficacy berpengaruh signifikan terhadap kinerja individual distributor.

Dari hasil pengujian di atas diperoleh angka $R$ sebesar 0,513 . Nilai ini menunjukkan bahwa korelasi atau hubungan variabel independen dengan variabel dependen cukup kuat. Hal ini berarti sekitar 51,3\% variabel Kinerja Individual (Y) dipengaruhi oleh faktor kepuasan kerja (X1), motivasi (X2), komunikasi interpersonal (X3), self esteem (X4) dan self efficacy (X5) sedangkan sebagian besar sisanya yaitu $48,7 \%$ dipengaruhi oleh faktor lain di luar model.

Nilai R square atau koefisien determinasi adalah 0,263 hal ini berarti bahwa hanya $26,3 \%$ variabel dependen bisa dijelaskan oleh variabel independen sedangkan sisanya $73,7 \%$ dijelaskan oleh variabel lain di luar model. Standar Error of the Estimate adalah 0,37832 atau 37,83\% artinya bahwa makin kecil Std. Error of the Estimate-nya akan membuat regresi semakin tepat memprediksi variabel dependen. Nilai Signifikansi F sebesar 0,000 $<0,05$ hasil ini menunjukkan adanya pengaruh yang sangat signifikan antara variabel kepuasan kerja, motivasi, komunikasi interpersonal, self esteem dan self efficacy terhadap kinerja individual Distributor Tiens Unicore di Makassar.

Dari persamaan regresi berganda tersebut di atas terlihat bahwa nilai konstanta sebesar 1,719 yang menyatakan bahwa jika tidak ada variabel dorongan akan kepuasan kerja, dorongan motivasi dan dorongan komunikasi interpersonal, dorongan self esteem, dorongan self efficacy maka kinerja individual akan meningkat sebesar 1,719 atau dapat dikatakan bahwa meningkatnya kepuasan kerja, motivasi, komunikasi interpersonal, self esteem dan self efficacy distributor akan berbanding lurus dengan meningkatnya kinerja individual distributor Tiens Unicore kota Makassar.

Hasil Uji Hipotesis 1; Pengujian kepuasan kerja berpengaruh signifikan terhadap kinerja individual didapatkan nilai t sebesar 2,393 dengan nilai signifikansi sebesar 0,019 atau di bawah $0,05(\mathrm{P}<0,05)$ sehingga dengan hasil pengujian tersebut menunjukkan bahwa variabel Kepuasan Kerja berpengaruh signifikan terhadap kinerja individual sehingga dapat disimpulkan bahwa H1 diterima. Hasil ini mendukung penelitian dari Maryani dan Supomo (2001) yang menyatakan bahwa kepuasan kerja sangat berpengaruh terhadap kinerja individual. Hasil penelitian ini juga mendukung penelitian Engko (2006). Dalam bidang network marketing atau pemasaran jaringan produktivitas dapat ditingkatkan melalui peningkatan kepuasan kerja, karena kepuasan kerja memberikan semangat kepada distributor untuk meningkatkan kinerja. Untuk itu, perlu diperhatikan agar distributor sebagai penunjang terciptanya produktivitas kerja dalam bekerja senantiasa disertai dengan perasaan senang dan tidak terpaksa sehingga akan tercipta kepuasan kerja para distributor.

Hasil Uji Hipotesis 2; Pengujian motivasi berpengaruh signifikan terhadap kinerja individual didapatkan nilai t sebesar 2,054 dengan nilai signifikansi sebesar 0,043 atau di bawah $0,05(\mathrm{P}<0,05)$ sehingga dengan hasil pengujian tersebut menunjukkan bahwa variabel Motivasi berpengaruh positif dan signifikan terhadap kinerja individual 
sehingga dapat disimpulkan bahwa H2 diterima. Dari hasil pengujian hipotesis, ditemukan hasil bahwa motivasi berpengaruh signifikan terhadap kinerja individual. Dalam bisnis network marketing, motivasi penting karena dengan motivasi ini diharapkan setiap individu distributor mau bekerja keras dan antusias untuk mencapai produktivitas kerja yang tinggi. Motivasi terhadap diri sendiri harus tetap dipelihara, karena modal utama yang dibutuhkan untuk mencapai sukses di bisnis pemasaran jaringan adalah impian atau motivasi diri untuk sukses. Dari hasil ini, dapat disimpulkan bahwa kinerja individual distributor Tiens Unicore di kota Makassar dipengaruhi oleh Motivasi atau impian yang kuat dari para distributornya untuk sukses. Hasil penelitian ini mendukung penelitian Efendi (2007) yang menemukan bahwa Motivasi kerja mempunyai pengaruh positif terhadap kinerja individual.

Hasil Uji Hipotesis 3; Pengujian komunikasi interpersonal berpengaruh signifikan terhadap kinerja individual didapatkan nilai t sebesar 1,797 dengan nilai signifikansi sebesar 0,076 atau di atas 0,05 (P>0,05). Nilai standardized coefisients beta sebesar 0,190 merupakan variabel yang paling rendah tingkat pengaruhnya terhadap kinerja individual yaitu sebesar 19\% sehingga dengan hasil pengujian tersebut menunjukkan bahwa variabel komunikasi interpersonal tidak berpengaruh signifikan terhadap kinerja individual sehingga dapat disimpulkan bahwa $\mathrm{H} 3$ ditolak. Penelitian ini tidak mendukung penelitian Chandra (2007) yang menemukan adanya pengaruh antara komunikasi interpersonal para leader MLM KK terhadap motivasi dan Kinerja distributor. Hasil penelitian ini menunjukkan hasil yang tidak signifikan terhadap Kinerja Individual. Hasil yang tidak signifikan mungkin disebabkan karena distributor dalam peningkatan kinerjanya tidak memperhatikan tingkat kemahiran dalam berkomunikasi interpersonal melainkan memanfaatkan alat bantu berupa buku-buku, kaset maupun $\mathrm{CD}$ profil perusahaan serta pertemuan yang dalam hal ini termasuk dalam komponen komunikasi massa.

Hasil Uji Hipotesis 4; Self esteem berpengaruh signifikan terhadap kinerja individual didapatkan nilai t sebesar 2,137 dengan nilai signifikansi sebesar 0,035 atau di bawah 0,05 $(\mathrm{P}<0,05)$. Dari hasil pengujian, terlihat bahwa variabel self esteem merupakan variabel yang paling dominan mempengaruhi kinerja individual distributor. Hal ini tampak pada nilai Standardized Cefisients Beta sebesar 0,232 atau pengaruhnya terhadap kinerja individual sebesar 23,2\% dengan tingkat signifikansi di bawah 0,05 sehingga dengan hasil pengujian tersebut menunjukkan bahwa variabel komunikasi interpersonal tidak berpengaruh signifikan terhadap kinerja individual sehingga dapat disimpulkan bahwa H4 diterima. Penelitian ini mendukung penelitian Engko (2006) yang menemukan ada hubungan positif antara Self esteem dan kinerja individual. Dari penelitian ini, dapat disimpulkan bahwa distributor Tiens Unicore di Makassar memiliki self esteem yang tinggi dalam meningkatkan kinerjanya.

Hasil penelitian ini menemukan adanya pengaruh yang positif dan signifikan antara self esteem terhadap Kinerja Individual. Hal ini disebabkan karena self esteem merupakan keyakinan nilai diri sendiri berdasarkan evaluasi diri secara 
keseluruhan. Perasaan-perasaan self esteem, pada kenyataannya terbentuk oleh keadaan distributor dan bagaimana orang lain memperlakukannya. Self esteem merupakan evaluasi secara menyeluruh dari dimensi diri. Self esteem juga mengacu pada harga diri atau self Image dan merefleksikan kepercayaan diri serta kepuasan individu terhadap diri mereka.

Hasil Uji Hipotesis 5; Pengujian self efficacy berpengaruh signifikan terhadap kinerja individual didapatkan nilai t sebesar 2,011 dengan nilai signifikansi sebesar 0,047 atau di bawah $0,05(\mathrm{P}<0,05)$ sehingga dengan hasil pengujian tersebut menunjukkan bahwa variabel self efficacy berpengaruh positif dan signifikan terhadap kinerja individual sehingga dapat disimpulkan bahwa H5 diterima. Hasil ini mendukung penelitian Philip dan Gully (1997) dalam Engko (2006). Self efficacy dapat dikatakan sebagai faktor personal yang membedakan setiap individu dan perubahan self efficacy dapat menyebabkan terjadinya perubahan perilaku terutama dalam penyelesaian tugas dan tujuan. Penelitian ini menemukan bahwa self efficacy berhubungan positif dengan penetapan tingkat tujuan. Individu yang memiliki self efficacy tinggi akan mampu menyelesaikan pekerjaan atau mencapai tujuan tertentu, mereka juga akan berusaha menetapkan tujuan lain yang tinggi. Distributor yang memiliki self efficacy tinggi akan mencurahkan semua usaha dan perhatiannya sesuai dengan tuntutan situasi tersebut dalam mencapai tujuan dan kinerja yang telah ditentukannya.

\section{SIMPULAN}

Penelitian ini dilakukan untuk mengetahui sejauhmana pengaruh kepuasan kerja, motivasi, komunikasi interpersonal, self esteem dan self efficacy terhadap kinerja individual. Penelitian ini mengambil sampel distributor aktif perusahaan network marketing Tiens Unicore di Makassar. Sebagai variabel independen penelitian ini adalah kepuasan kerja, motivasi, komunikasi interpersonal, self esteem dan self efficacy serta kinerja individual sebagai variabel dependen. Berdasarkan pengujian hipotesis dapat ditarik kesimpulan: Pertama, Pengujian hipotesis 1 (H1) diterima. Kepuasan kerja berpengaruh positif dan signifikan terhadap kinerja individual. Kepuasan kerja memberi pengaruh yang besar dalam meningkatkan kinerja individual para distributor. Kedua, Pengujian hipotesis 2 (H2) diterima. Motivasi berpengaruh positif dan signifikan terhadap kinerja individual. Motivasi dapat diartikan sebagai kekuatan (energi) seseorang yang dapat menimbulkan tingkat persistensi dan antusiasmenya dalam melaksanakan suatu kegiatan baik yang bersumber dari dalam diri individu itu sendiri maupun dari luar individu. Ketiga, Pengujian Hipotesis (H3) ditolak. komunikasi interpersonal tidak berpengaruh signifikan terhadap kinerja individual. Adanya komunikasi interpersonal ternyata tidak memberikan pengaruh yang besar terhadap peningkatan kinerja individual distributor melainkan dengan komunikasi massa misalnya disebuah event atau training yang melibatkan banyak peserta sehingga menimbulkan motivasi dan gesekan positif yang membuat distributor 
bisa berkembang dan Kinerja Individualnya meningkat. Keempat, Pengujian hipotesis 4 (H4) diterima. Self esteem berpengaruh signifikan terhadap kinerja individual. Self esteem merupakan evaluasi secara menyeluruh dari dimensi diri. Self esteem juga mengacu pada harga diri atau self Image dan merefleksikan kepercayaan diri serta kepuasan individu terhadap diri mereka. Variabel self esteem merupakan variabel yang paling dominan dalam penelitian ini yang mempengaruhi kinerja individual. Kelima, Pengujian hipotesis 5 (H5) diterima. Self efficacy berpengaruh signifikan terhadap Kinerja Individual. Self efficacy dapat dikatakan sebagai faktor personal yang membedakan setiap individu dan perubahan self efficacy dapat menyebabkan terjadinya perubahan perilaku terutama dalam penyelesaian tugas dan tujuan. Penelitian ini menemukan bahwa self efficacy berhubungan positif dengan penetapan tingkat tujuan. Individu yang memiliki self efficacy tinggi akan mampu menyelesaikan pekerjaan atau mencapai tujuan tertentu, mereka juga akan berusaha menetapkan tujuan lain yang tinggi.

Penelitian ini mengambil 96 sampel Distributor Tiens Unicore di Makassar. Sebagaimana lazimnya suatu penelitian empiris, hasil penelitian ini juga mengandung keterbatasan yaitu Penelitian ini hanya penguji pengaruh variabel independen terhadap variabel dependen. Variabel independen dalam penelitian ini adalah kepuasan kerja, motivasi, komunikasi interpersonal, self esteem dan self efficacy sedangkan variabel dependen adalah kinerja individual. Hasil penelitian menunjukkan tingkat pengaruh yang tidak begitu tinggi. Hal ini mengindikasikan bahwa perlu mempertimbangkan menggunakan variabel moderating atau intervening serta menambahkan beberapa variabel.

Penelitian ini diharapkan mempunyai implikasi bagi Distributor Tiens Unicore di Makassar, para peneliti dan akademisi. Pertama, Bagi distributor Tiens Unicore, self esteem para distributor dipertahankan ataupun ditingkatkan dan komunikasi interpersonal diperbaiki sehingga kinerja individual dapat meningkat. Kedua, Bagi para peneliti, hasil penelitian ini diharapkan dapat mendorong dan memotivasi peneliti berikutnya untuk menambahkan beberapa variabel antara lain komunikasi massa maupun variabel personality lainnya. Ketiga, Bagi akademisi, hasil penelitian ini diharapkan dapat memberikan konstribusi dan khasanah pendidikan bagi banyak orang.

\section{DAFTAR PUSTAKA}

As'ad. 2003. Psikologi Islam, Seri Sumber Daya Manusia. Yogyakarta: Liberty.

Bandura, A. 1997. Self efficacy, Toward a Unifying Theory of Behavioural Change, Psychology Review.

Chandra, E.S. 2007. Pengaruh Kemampuan Leader MLM KK Indonesia dalam berkomunikasi Interpersonal terhadap Kinerja dan Motivasi Distributor. Skripsi. Surabaya: Universitas Kristen Patra. 
Engko, C. 2006. Pengaruh Kepuasan Kerja terhadap Kinerja Individual dengan Self esteem dan Self efficacy sebagai variabel Intervenin. Padang: Simposium Nasional Akuntansi 9.

Efendi, D. 2007. Pengaruh Kepuasan Kerja dan Motivasi Kerja terhadap Kinerja Individual. Universitas Muhammadiyah Malang.

Effendy, O.U. 2003. Ilmu, Teori dan Filisafat Komunikasi.Cet. Ke-3. Bandung: Citra Aditya Bakti.

Handoko, T.H. 2001. Manajemen Personalia dan Sumber Daya Manusia. Yogyakarta: BPFE Pres.

Hasibuan, M. 2003. Organisasi dan Motivasi, Dasar Peningkatan Produktivitas. Jakarta: Bumi Aksara.

Heidjrahman, S.H. 2002. Manajemen Personalia. Yogyakarta: BPFE.

Kiyosaki, R. 2001. The Cash Flow Quadrant. Jakarta: Gramedia Pustaka Utama.

Kreitner, R., Knicky, A. 2003. Perilaku Organisasi, Edisi Pertama. Jakarta: Salemba Empat.

Liliweri, A. 1997. Komunikasi antarpribadi. Jakarta: Salemba Empat.

Martoyo, S. 2000. Manajemen Sumber Daya Manusia. Yogyakarta: BPFE.

Mulyana, D. 2000. Ilmu Komunikasi Suatu Pengantar. Bandung: Remaja Rosdakarya.

Onong, E. 2001. Ilmu, Teori dan Filsafat Komunikasi. Jakarta: Erlangga.

Prasetyo, E., Wahyuddin. 2005. Pengaruh Kepuasan Kerja dan Motivasi Kerja terhadap Produktifitas Kerja Karyawan Riyadi Palace Hotel di Surakarta. Program Pascasarjana Universitas Muhammadiah Surakarta.

Siagian, S.P. 2002. Manajemen sumber Daya manusia. Jakarta: Bumi Aksara.

Supomo, B., Dwi, M. Studi Empiris Pengaruh Kepuasan Kerja terhadap Kinerja Individual. Jurnal Bisnis dan Akuntansi. Vol 3 No. 1 hal. 367-376.

Timpe, D.A. 1999. Produktivitas, Seri Manajemen Sumber Daya Manusia. Jakarta: Alex Media Komputindo. 